\title{
Spectrophotometric method for the assay of human blood coagulation factor VIII
}

Citation for published version (APA):

van Dieijen, G., van Dieijen-Visser, M. P., Franssen, J., \& Hemker, H. C. (1987). Spectrophotometric method for the assay of human blood coagulation factor VIII. Haemostasis, 17(1-2), 14-24.

https://doi.org/10.1159/000215554

Document status and date:

Published: 01/01/1987

DOI:

10.1159/000215554

Document Version:

Publisher's PDF, also known as Version of record

\section{Please check the document version of this publication:}

- A submitted manuscript is the version of the article upon submission and before peer-review. There can be important differences between the submitted version and the official published version of record.

People interested in the research are advised to contact the author for the final version of the publication, or visit the DOI to the publisher's website.

- The final author version and the galley proof are versions of the publication after peer review.

- The final published version features the final layout of the paper including the volume, issue and page numbers.

Link to publication

\footnotetext{
General rights rights.

- You may freely distribute the URL identifying the publication in the public portal. please follow below link for the End User Agreement:

www.umlib.nl/taverne-license

Take down policy

If you believe that this document breaches copyright please contact us at:

repository@maastrichtuniversity.nl

providing details and we will investigate your claim.
}

Copyright and moral rights for the publications made accessible in the public portal are retained by the authors and/or other copyright owners and it is a condition of accessing publications that users recognise and abide by the legal requirements associated with these

- Users may download and print one copy of any publication from the public portal for the purpose of private study or research.

- You may not further distribute the material or use it for any profit-making activity or commercial gain

If the publication is distributed under the terms of Article $25 \mathrm{fa}$ of the Dutch Copyright Act, indicated by the "Taverne" license above, 


\title{
Spectrophotometric Method for the Assay of Human Blood Coagulation Factor VIII
}

\author{
G. van Dieijen a, M.P. van Dieijen-Visser ${ }^{\text {b }, J . ~ F r a n s s e n ~}{ }^{\text {a }, H . C . ~ H e m k e r ~}{ }^{\text {a }}$ \\ a Department of Biochemistry, University of Limburg, Maastricht; \\ ${ }^{b}$ Department of Clinical Chemistry, De Wever Hospital, Heerlen, The Netherlands
}

Key Words. Factor VIII, spectrophotometric assay - Clotting assay, 1-stage . Chromogenic substrate

\begin{abstract}
A spectrophotometric method for the assay of human blood coagulation factor VIII in plasma is presented. The chromogenic assay for factor VIII:C in plasma is performed in 3 steps: (1) activation of factor VIII by thrombin; (2) activation of factor X in a mixture of factor $\mathrm{X}$, factor IXa, phospholipids/ $\mathrm{Ca}^{2+}$ and plasma containing activated factor VIII, and (3) determination of the rate of factor Xa formation with the chromogenic substrate S2337. Within-assay variation was between 5 and $6.9 \%$ for factor VIII:C activities between 20 and $150 \%$. Clotting and chromogenic factor VIII:C activities were compared in plasma of 50 normal healthy donors (coefficient of correlation $r=0.83$ ).
\end{abstract}

\section{Introduction}

Factor VIII or antihemophilia globulin A is a plasma protein that is essential for normal hemostasis (see [1] for review). Its congenital absence is by far the most common cause of congenital bleeding tendency. The procoagulant protein (factor VIII:C) occurs in plasma tightly bound to the von Willebrand factor (factor VIII:vWF). Factor VIII:C and vWF together form the factor VIII complex. Factor VIII:C appears responsible for normal thrombin formation, whereas factor VIII:vWF is required for platelet-vessel wall interaction. (For reviews on factor VIII complex and vWF see [2, 3].)
If factor VIII:C is congenitally deficient, factor VIII:vWF is normal. If factor VIII:vWF is deficient, factor VIII:C is to a varying degree also.

A widely used method to determine factor VIII in plasma is the 1-stage clotting assay introduced in 1962 by Hardisty et al. [4]. This assay is based on the property of factor VIII to correct the prolonged clotting time of hemophiliac plasma to a degree determined by the amount of factor VIII present.

A new assay method for the determination of factor VIII using a chromogenic substrate for factor Xa appeared feasible after kinetic studies on the role of factor VIII in 
the intrinsic factor-X-activating complex [5]. In this paper, we describe a spectrophotometric assay for factor VIII in human plasma and compare the properties and precision of the assay with the 1-stage clotting assay.

\section{Materials and Methods}

S2337, Bz-Ile-Glu(Piperidyl)-Gly-Arg-p-nitroanilide and S2238, H-D-Phe-Pip-Arg-p-nitroanilide were obtained from Kabi AB, Sweden. Egg-phosphatidylcholine (egg-PC) was from Koch-Light, UK, and brain-phosphatidylserine (brain-PS) was from Sigma, St. Louis, Mo., USA. Hirudin was from Pentapharm, Basel, Switzerland. Fatty acid free human albumin and soybean trypsin inhibitor were obtained from Sigma. Factor-deficient plasmas were purchased from George King Biomedical, Overland Park, Kans., USA. The batch numbers used were factor VIII, GK 837-314; high molecular weight kininogen, GK 1603D30; factor XII, GK 1202-921; factor XI, GK 1110 N19; prekallikrein, GK 1704-124; passavoy GK 1501-625; factor V, GK 503-223, and von Willebrand, GK 1403-93. The factor-deficient plasmas from General Diagnostics were of the following lot numbers: factor VIII, 4G926; factor X, 4H699; factor VII, 4J759. Factor-VIII-deficient plasma (WH) and factor-IX-deficient plasma were obtained from local patients. Kaolin (light) was from Koch-Light. Inosithin was from Associated Concentrates, New York, USA.

\section{Proteins}

Bovine factor $\mathrm{X}$ (factor $\mathrm{X}_{2}$ was used in this work), factor IXa and thrombin were purified and activated as published before [5]. Phospholipid vesicles consisting of $40 \%$ brain-PS and $60 \%$ egg-PC were made by sonication at $0^{\circ} \mathrm{C}$ in a buffer of $50 \mathrm{mM}$ tris- $\mathrm{HCl}$, $175 \mathrm{mM} \mathrm{NaCl}, \mathrm{pH} 7.9$, as described before [6].

\section{Human Donor Plasmas}

Blood was obtained from healthy volunteers after informed consent by venipuncture using a $1.2 \times$ $40 \mathrm{~mm}$ needle, discarding the first $2 \mathrm{ml}$. Blood $(9 \mathrm{ml})$ was mixed with $1 \mathrm{ml}$ of $0.1 \mathrm{M}$ trisodium citrate in a plastic tube and centrifuged for $30 \mathrm{~min}$ at $2,000 \mathrm{~g}$. The plasma was aspirated and made platelet-free by a centrifugation at $4^{\circ} \mathrm{C}$ for $15 \mathrm{~min}$ at $14,000 \mathrm{~g}$ in the
Beckmann J-21 rotor. The plasma samples were frozen and stored at $-70^{\circ} \mathrm{C}$ in small portions. Reference pool plasma was made by mixing $1 \mathrm{ml}$ of each of the donor plasmas $(n=50)$. It is assumed that factor VIII:C activity in the reference plasma is $1 \mathrm{U} / \mathrm{ml}$. Different dilutions of the reference pool were used to obtain standard c-q reference curves.

\section{Spectrophotometric Assay for Factor VIII}

(Standard Factor VIII Assay)

Forty microliters of human plasma (or a sample in which factor VIII must be determined) is added to a prewarmed mixture of $910 \mu \mathrm{l}$ buffer containing $175 \mathrm{mM} \mathrm{NaCl}, 50 \mathrm{~m} M$ tris- $\mathrm{HCl}, \mathrm{pH} 7.9,0.5 \mathrm{mg} / \mathrm{ml}$ human albumin and $50 \mu \mathrm{l}$ of $60 \mathrm{n} M(6 \mathrm{NIH} \mathrm{U} / \mathrm{ml})$ of thrombin. After incubation for $1 \mathrm{~min}$ at $37^{\circ} \mathrm{C}, 500 \mu \mathrm{l}$ of the plasma, containing activated factor VIII, is added to a second tube containing $450 \mu \mathrm{l}$ of a prewarmed $\left(37^{\circ} \mathrm{C}\right)$ mixture of phospholipids, $\mathrm{CaCl}_{2}$ and factor IXa. Factor $\mathrm{X}$ activation is started by addition to the reaction mixture of $50 \mu \mathrm{l}$ of $10 \mu \mathrm{M}$ factor $\mathrm{X}$, at the same time as the activated plasma. The final composition of the reaction mixture $(1 \mathrm{ml})$ is: $20 \mu \mathrm{l}$ of plasma, added as $500 \mu 1$ thrombin-activated plasma; $0.5 \mu M$ factor X, $50 \mathrm{n} M$ factor IXa, $20 \mu M$ phospholipid vesicles ( $40 \mathrm{~mol} \% \mathrm{PS} / 60 \mathrm{~mol} \% \mathrm{PC}) ; 1.5 \mathrm{nM}$ thrombin, $0.5 \mathrm{mg} / \mathrm{ml}$ human albumin in a buffer containing $175 \mathrm{mM} \mathrm{NaCl}, 50 \mathrm{mM}$ tris- $\mathrm{HCl}(\mathrm{pH} \mathrm{7.9)}$ and $6 \mathrm{~m} M \mathrm{CaCl}_{2}$.

After 1 and $2 \mathrm{~min}$, samples from the reaction mixture (usually $0.1 \mathrm{ml}$ ) were added to a cuvette $\left(37^{\circ} \mathrm{C}\right.$ ) with $0.8 \mathrm{ml}$ buffer of $175 \mathrm{mM} \mathrm{NaCl}, 50 \mathrm{~m} M$ tris- $\mathrm{HCl}$, $\mathrm{pH} 7.9,20 \mathrm{~m} M$ EDTA, 0.5 antithrombin units of hirudin and $0.5 \mathrm{mg} / \mathrm{ml}$ human albumin. After addition of $0.1 \mathrm{ml} \mathrm{S} 2337$ ( $2.35 \mathrm{mM} ; 25$ A316 units $/ \mathrm{ml}$ ), the absorbance increase at $405 \mathrm{~nm}$ was recorded for 2-3 min using a Beckman Model 25 spectrophotometer. From the absorbance change, the amount of factor Xa present was calculated using a calibration curve made with a factor Xa preparation of known concentration. The rate of factor Xa formation was calculated from the amount of factor Xa present after 1 and $2 \mathrm{~min}$ and was corrected for the rate found in a blank experiment run without plasma.

\section{Factor VIII Clotting Assay}

A 1-stage clotting assay for factor VIII [4] was carried out by preincubating for $6 \mathrm{~min}$ at $37^{\circ} \mathrm{C} 50 \mu \mathrm{l}$ factor-VIII-deficient plasma, $50 \mu \mathrm{l}$ kaolin-inosithin in Michaclis buffer, and $50 \mu \mathrm{l}$ of the factor VIII sample. 
After $6 \mathrm{~min}, 50 \mu \mathrm{l} 1 / 30 \mathrm{M} \mathrm{CaCl}_{2}$ was added to start clot formation. The clotting time was determined by tilting the tubes. The amount of factor VIII present was determined from a reference curve. This curve is a double logarithmic plot of the clotting times (determined in duplicate) of 10 different dilutions of reference plasma. The composition of Michaelis buffer was $0.0285 M \mathrm{Na}$ acetate, $0.0285 M \mathrm{Na}$ barbiturate, $0.116 \mathrm{M} \mathrm{NaCl}(\mathrm{pH} 7.4)$. The kaolin-inosithin suspension contained $5 \mathrm{mg} / \mathrm{ml} \mathrm{kaolin} \mathrm{and} 1 \mathrm{mg} / \mathrm{ml}$ inosithin.

\section{Statistical Analysis of Data}

The significance of differences between 2 values was tested by a paired Student $t$ test. $\mathrm{CV}$ is the coefficient of variation, the standard deviation is expressed as a percentage of the mean.

\section{Results}

\section{Determination of Optimal Assay}

\section{Conditions}

In intrinsic factor $\mathrm{X}$ activation, factor $\mathrm{X}$ is cleaved to factor Xa by the enzyme factor IXa, and the rate of this reaction is strongly enhanced in the presence of the nonenzymatic accessory components, i.e. activated factor VIII and phospholipids. Factor VIIIa works by at least 2 different mechanisms: it increases the affinity of factor IXa for binding to phospholipids [7] by a factor of about 100 and it also increases the $V_{\max }$ turnover number of factor Xa formation by factor IXa about 1,000-fold [5]. The experimental conditions for the factor VIII assay in plasma as described in 'Materials and Methods' were based on the observations done in purified systems [5, 7]. The factor $\mathrm{X}$ concentration in the assay $(0.5 \mu M)$ was chosen well above the $\mathrm{K}_{\mathrm{m}}$ for factor $\mathrm{X}(0.06 \mu M)$. A phospholipid vesicle concentration of $20 \mu M$ was selected in the assay because the rate of factor $\mathrm{Xa}$ formation strongly increases between 0 and $5 \mu M$, reaches a plateau between 10 and
$50 \mu M$, and decreases at higher phospholipid concentration. The factor IXa concentration used in the assay is $50 \mathrm{nM}$ and is based on the experiment shown in figure 1 . The rate of factor Xa formation increases with the factor IXa concentration and levels off at higher factor IXa concentrations. In the absence of plasma factor VIII, a low rate of factor Xa formation proportional with factor IXa is found. When this rate is subtracted from the rate measured in the presence of plasma, a plateau level is obtained, indicating apparent saturation of the factor-X-activating system with factor IXa. A factor IXa concentration in the assay of $50 \mathrm{nM}$ approaches saturation. When $20 \mu \mathrm{l}$ plasma is present in the assay, the background rate without plasma is about $10 \%$ of the rate measured in the presence of plasma.

Factor VIII must be activated before it can participate in factor $\mathrm{X}$ activation, and thrombin is a well-known activator of factor VIII. Activated factor VIII is not stabile and rapidly inactivates $[2,6]$. Therefore, the activation of factor VIII in plasma by thrombin was carried out in a 1-min period just before the start of each factor $\mathrm{X}$ activation reaction. Optimal conditions for activation were established by the experiments shown in figure 2. Plasma was incubated at varying thrombin concentrations and after $1 \mathrm{~min}$, the activated plasma sample was transferred to a mixture of phospholipid, $\mathrm{Ca}^{2+}$ and factor IXa. Simultaneous with the activated plasma, factor $\mathrm{X}$ was added and the time course of factor $\mathrm{Xa}$ formation was determined during $3 \mathrm{~min}$. As shown in figure 2, no factor $\mathrm{X}$ activation is found within $3 \mathrm{~min}$ when thrombin is omitted from the plasma activation mixture. The rate of factor $\mathrm{Xa}$ formation increases when increased amounts of thrombin are used $(0-1.8 \mathrm{n} M)$ to activate the 


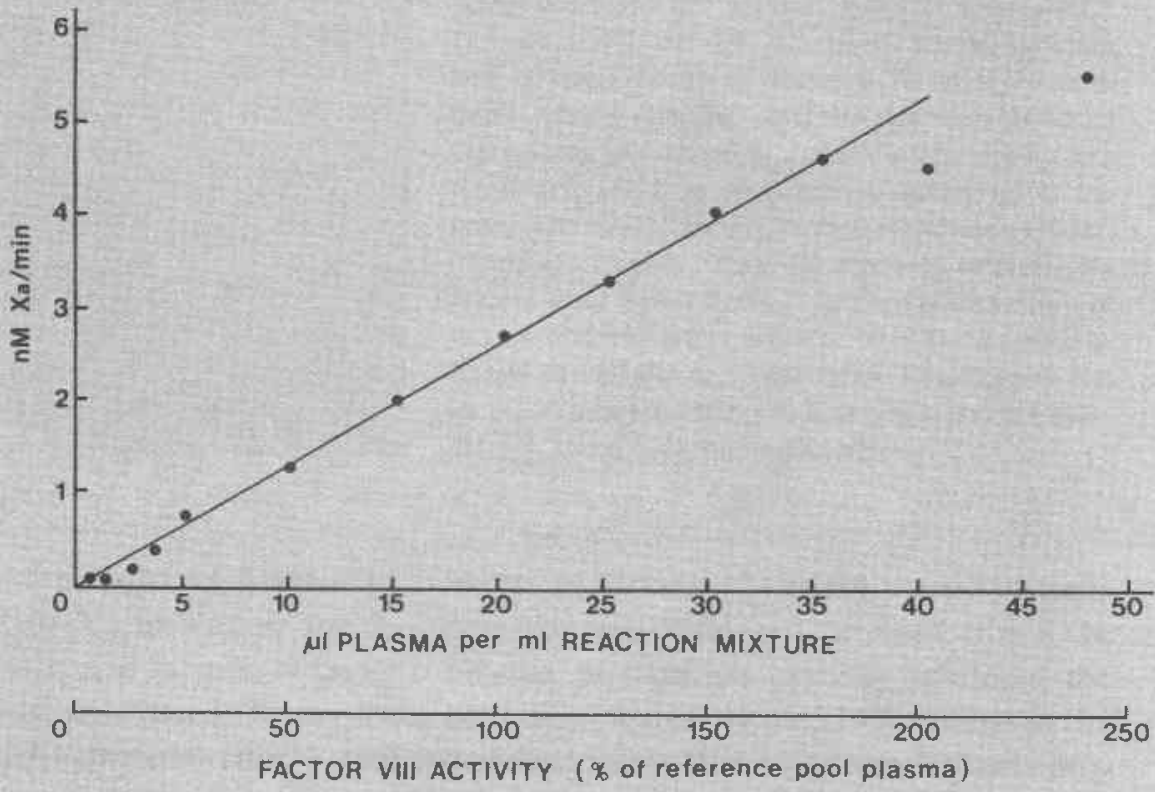

Fig. 1. Determination of the optimal factor IXa concentration. Forty microliter of reference pool plasma was added to $960 \mu \mathrm{l}$ of a prewarmed $\left(37^{\circ} \mathrm{C}\right)$ solution of $3.0 \mathrm{n} M$ thrombin in a buffer containing $50 \mathrm{mM}$ tris- $\mathrm{HCl}, 175 \mathrm{mM} \mathrm{NaCl}, \mathrm{pH} 7.9$, and $0.5 \mathrm{mg} / \mathrm{ml}$ of human albumin. After exactly $1 \mathrm{~min}$ at $37^{\circ} \mathrm{C}, 500 \mu \mathrm{l}$ of the plasma thrombin mixture was transferred to a second prewarmed tube containing $450 \mu \mathrm{l}$ of a mixture of phospholipids, $\mathrm{CaCl}_{2}$ and varying amounts of factor IXa. Together with the activated plasma, $50 \mu \mathrm{l}$ of factor $\mathrm{X}(10 \mu M)$ was added to start factor $\mathrm{Xa}$ formation. After 1 and $2 \mathrm{~min}$, samples of $100 \mu \mathrm{l}$ were added to prewarmed $\left(37^{\circ} \mathrm{C}\right)$ cuvettes containing $0.8 \mathrm{ml}$ of a buffer containing $50 \mathrm{mM}$ tris-

factor VIII present. No further increase (or decrease) in the time course of factor Xa formation was observed at thrombin concentrations between 1.8 and $6 \mathrm{nM}$. This result suggests that optimal activation of factor VIII in plasma is obtained under these conditions.
$\mathrm{HCl}, 175 \mathrm{mM} \mathrm{NaCl}, 20 \mathrm{mM}$ EDTA, pH 7.9, and $0.5 \mathrm{mg} / \mathrm{ml}$ human albumin. To the cuvette was added $0.1 \mathrm{ml}$ chromogenic substrate $\mathrm{S} 2337(2.35 \mathrm{~m} M)$. The absorbance change at $405 \mathrm{~nm}$ was measured and used to calculate the amount of factor $\mathrm{Xa}$ present as described in 'Materials and Methods'. The composition of the factor-X-activating mixture of $1 \mathrm{ml}$ was: $20 \mu \mathrm{l}$ human plasma, $1.5 \mathrm{n} M$ thrombin, $20 \mu M$ phospholipid vesicles consisting of $40 \%$ phosphatidylserine and $60 \%$ phosphatidylcholine, factor IXa as indicated in the figure, $0.5 \mu M$ factor $\mathrm{X}, 50 \mathrm{~m} M$ tris- $\mathrm{HCl}, 175 \mathrm{mM} \mathrm{NaCl}$, $6 \mathrm{mM} \mathrm{CaCl} 2, \mathrm{pH} 7.9$, and $0.5 \mathrm{mg} / \mathrm{ml}$ human albumin. - = Without plasma; $\boldsymbol{\Lambda}$ = with reference pool plasma; - = difference curve obtained by substraction.

The amounts of thrombin did not influence the factor Xa generation by a factor-VIIIindependent mechanism, as no activity was observed when factor VIII was absent (fig. 1) (see also below). Hence, in the standard assay procedure, plasma is activated for $1 \mathrm{~min}$ 


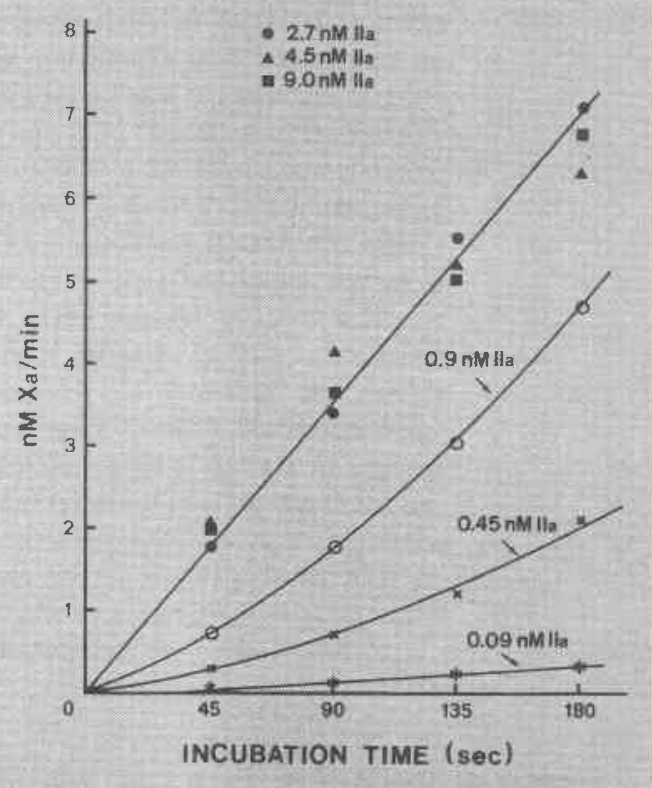

at a thrombin concentration of $3 \mathrm{n} M$. The time course of factor $\mathrm{Xa}$ formation was linear for at least $2 \mathrm{~min}$, and the rate of factor $\mathrm{Xa}$ formation was calculated from the amount of factor Xa present after 1 and $2 \mathrm{~min}$.

Hirudin is present in the cuvettes to inhibit the activity of thrombin on the chromogenic substrate S2337. Thrombin is formed from prothrombin present in the plasma sample during the factor $\mathrm{X}$ activation reaction. In the standard factor VIII assay containing $20 \mu \mathrm{l}$ plasma, $27 \mathrm{n} M$ thrombin is formed after $2 \mathrm{~min}$. The thrombin concentration was determined using S2238 as the chromogenic substrate for thrombin in a cuvette that contained soybean trypsin inhibitor to inactivate factor $\mathrm{Xa}$. Addition of hirudin $(0.5$ antithrombin units per cuvette) inhibited the thrombin activity on S2238 for $97.8 \%$. A much larger
Fig. 2. Determination of the optimal thrombin concentration for the activation of factor VIII in human plasma. Pool plasma $(40 \mu \mathrm{l})$ was added to $960 \mu \mathrm{l}$ of a buffer $\left(37^{\circ} \mathrm{C}\right)$ containing $50 \mathrm{~m} M$ tris- $\mathrm{HCl}$, $175 \mathrm{mM} \mathrm{NaCl}, \mathrm{pH} 7.9,0.5 \mathrm{mg} / \mathrm{ml}$ human albumin and varying amounts of thrombin $(0-6 \mathrm{nM})$ as indicated. After $1 \mathrm{~min}, 500 \mu \mathrm{l}$ of the thrombin-activated plasma was transferred to a reaction mixture for factor $\mathrm{X}$ activation, as described in the legend of figure 1 . The rate of factor $\mathrm{Xa}$ formation was as determined as in figure 1 from the amounts of factor $\mathrm{Xa}$ present after 1 and $2 \mathrm{~min}$. The final composition of the reaction mixture $(1 \mathrm{ml})$ was: $20 \mu l$ human plasma, $20 \mu M$ phospholipid, $50 \mathrm{n} M$ factor IXa, $0.5 \mu M$ factor $\mathrm{X}, 50 \mathrm{~m} M$ tris- $\mathrm{HCl}, 175 \mathrm{mM} \mathrm{NaCl}, 6 \mathrm{mM} \mathrm{CaCl}$, $\mathrm{pH} 7.9$, and $0.5 \mathrm{mg} / \mathrm{ml}$ human albumin.

excess of hirudin (5-50 antithrombin units per cuvette) could not be used, since the hirudin preparation partially inhibited the activity of factor Xa on S2337. When in the standard factor VIII assay hirudin was omitted from the cuvettes, $3.2 \pm 2.4 \%$ (mean \pm $\mathrm{SD} ; \mathrm{n}=111$ ), higher rates of factor $\mathrm{X}$ activation were found, indicating that the contribution of thrombin to the total hydrolysis of S2337 is relatively small.

\section{Properties of the Spectrophotometric Assay}

Linearity of the Assay. Varying amounts of reference pool plasma were added to our standard test system. As shown in figure 3 , a linear dependence between the rate of factor $\mathrm{Xa}$ formation and the plasma concentration is found between 5 and $30 \mu \mathrm{l}$ of plasma per milliliter reaction mixture. High amounts of plasma in the assay give rise to clot forma- 
Fig. 3. Linearity of the assay. Varying amounts of reference pool plasma were incubated with $3.0 \mathrm{nM}$ of thrombin in $1 \mathrm{ml}$. After $1 \mathrm{~min}$ at $37^{\circ} \mathrm{C}, 500 \mu \mathrm{l}$ of the mixture was transferred to $500 \mu \mathrm{l}$ of a reaction mixture for factor $\mathrm{X}$ activation. The amount of factor Xa formed was determined after 1 and $2 \mathrm{~min}$, as described in the legend of figure 1 . The reaction mixture with the amounts of activated plasma as indicated contained $1.5 \mathrm{n} M$ thrombin and further components for factor $\mathrm{X}$ activation as described in the legend of figure 2. An amount of $20 \mu$ of reference pool plasma in the factor $\mathrm{X}$ activation mixture was chosen as the condition for the standard factor VIII assay, the rate of factor $\mathrm{Xa}$ formation found was designated as the $1 \mathrm{U} / \mathrm{ml}$ value.

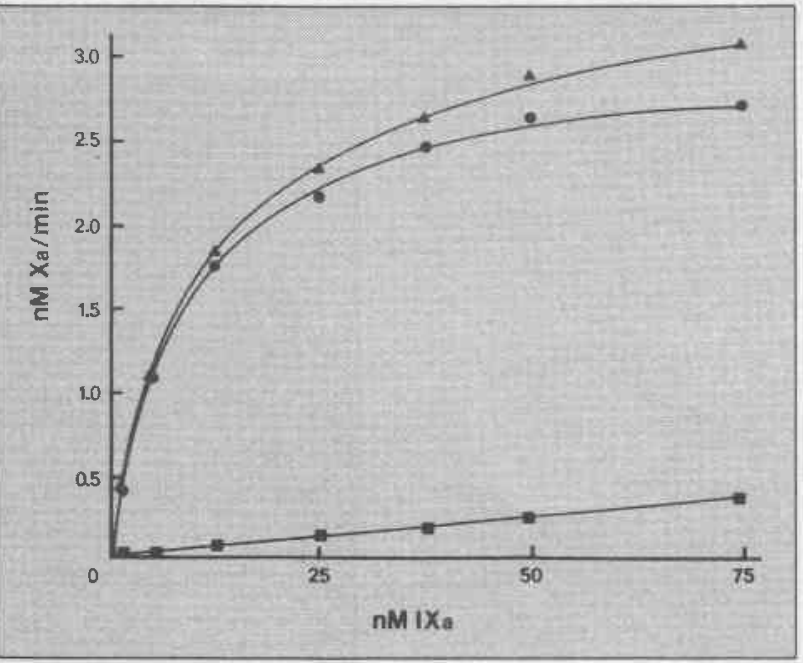

tion in the factor $\mathrm{X}$ activation mixture, which prevents accurate sampling. In the low range, a slight deviation from linearity is found. The same line is seen when the plasma samples are diluted in factor-VIIIdeficient plasma. In the standard factor VIII assay, an amount of $20 \mu \mathrm{l}$ plasma per milliliter reaction mixture is present. If values of below $20 \%$ of normal are to be expected in the abnormal sample, the sample volume is increased so as to ensure the equivalent amount of at least $2 \mu \mathrm{l}$ of normal plasma factor VIII in the test.

To demonstrate that the spectrophotometric assay depends on factor VIII and not on other clotting factors, we determined the factor VIII activity with the 2 assays in various factor-deficient plasmas. The results shown in table I indicate that background activity is measured in 3 different factorVIII-deficient plasmas and in plasma-of a patient with severe von Willebrand's disease. All other plasmas show factor VIII activities in the 2 assays comparable to the activities of normal individuals (fig. 4). This
Table I. Factor VIII content of various factor-deficient plasmas determined with the chromogenic assay and a clotting assay

\begin{tabular}{lll}
\hline Deficient plasma & \multicolumn{2}{l}{ Factor VIII, U/mI } \\
\cline { 2 - 3 } & $\begin{array}{l}\text { spectrophoto- } \\
\text { metric assay }\end{array}$ & $\begin{array}{l}\text { clotting } \\
\text { assay }\end{array}$ \\
\hline Factor XII & 0.70 & 0.76 \\
Factor XI & 0.82 & 0.76 \\
High molecular & & \\
$\quad$ weight kininogen & 0.46 & 0.60 \\
Prekallikrein & 1.05 & 0.76 \\
Passovoy & 0.42 & 0.68 \\
Factor V & 1.31 & 1.40 \\
Factor IX & 0.33 & 0.40 \\
Factor VII & 0.61 & 0.84 \\
Factor X & 0.79 & 0.80 \\
von Willebrand & 0.05 & 0.04 \\
Factor VIII (WH) & 0.05 & 0.01 \\
Factor VIII & & \\
$\quad$ (George King) & 0.05 & 0.01 \\
Factor VIII $\quad$ (Gen. Diagnostics) & 0.05 & 0.02 \\
\hline$\quad$ Ton & & \\
\hline
\end{tabular}

Factor VIII was assayed as described in 'Materials and Methods'. Values in italics were obtained using undiluted plasma. 


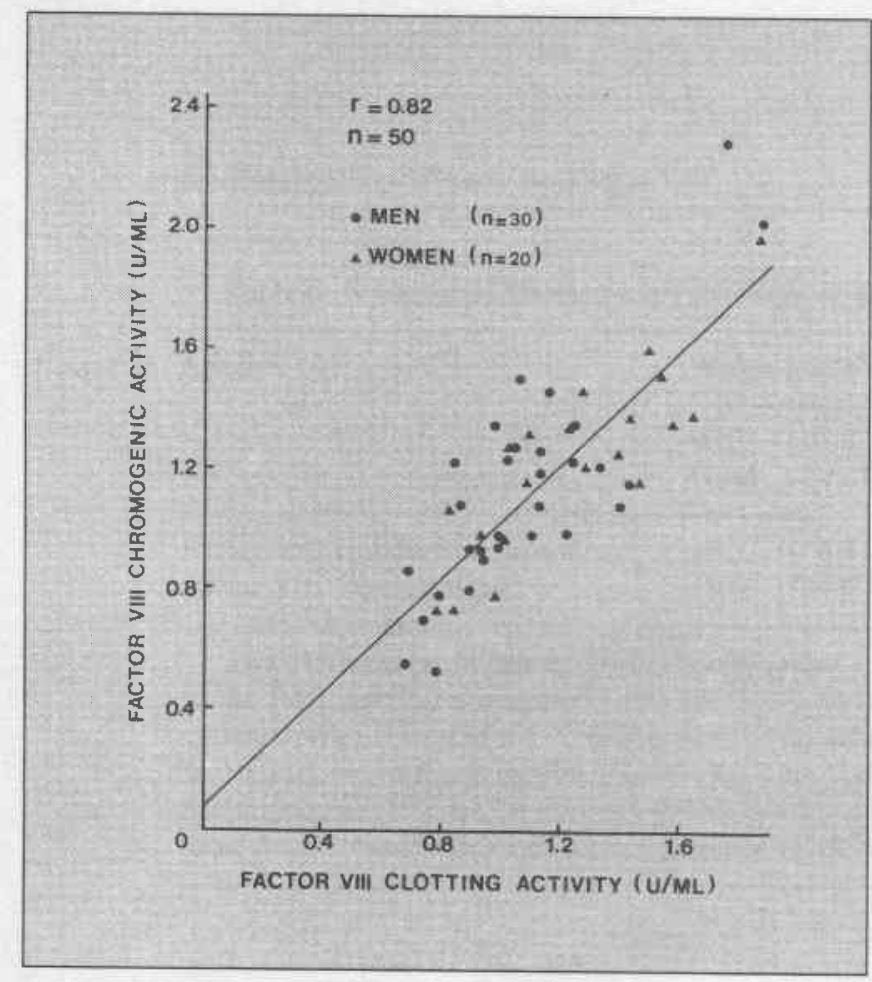

Fig. 4. Comparison of factor VIII activity determined by chromogenic and by clotting assay in 50 normal individuals. Blood was collected from healthy volunteers. Plasma preparation and the assays for factor VIII were carried out as described in 'Materials and Methods'. For 50 normal samples: $y=$ $0.0883+0.949 \mathrm{x} ; \mathrm{r}=0.82$.

result and the observation that the plasma dilution curves made in buffer (fig. 3) and in factor-VIII-deficient plasma are overlapping indicate that the assay is not affected by other plasma components.

Within-Assay Precision and BetweenAssay Precision. Precision of the 2 assays is shown in table II. Within-assay precision was estimated by testing several dilutions of the reference pool plasma 10 times each. Variation was expressed as percentage of the mean activity in plasma.

Between-assay precision of the chromogenic assay was determined by use of the reference pool plasma, stored in small portions at $-70^{\circ} \mathrm{C}$. On 10 consecutive days, 1 portion was assayed, from which the between-assay variation was calculated. Considerably smaller assay variations are observed from the chromogenic factor VIII assay than for the factor VIII clotting assay.

Comparison of the Chromogenic Method with the Clotting Assay - Variation in Factor VIII Activity in Normal Individuals. We determined factor VIII activity with the chromogenic method and the clotting assay in plasma of 50 healthy volunteers (30 men and 20 women). The results are shown in figure 4 . The coefficient of correlation between the 2 assay methods is 0.82 . The mean, the range and the interindividual variation for the 2 assays are presented in table III. No significant differences in factor VIII activity were observed between males and females. 
Table II. Within- and between-assay precision of the chromogenic and clotting assay

\begin{tabular}{|c|c|c|c|c|c|c|c|}
\hline \multirow[t]{2}{*}{ Assay } & \multicolumn{6}{|c|}{ Within-assay variation, $\%$} & \multirow{2}{*}{$\begin{array}{l}\text { Between- } \\
\text { assay } \\
\text { variation, \% }\end{array}$} \\
\hline & $\begin{array}{l}0.10 \\
\mathrm{U} / \mathrm{ml}\end{array}$ & $\begin{array}{l}0.20 \\
\mathrm{U} / \mathrm{ml}\end{array}$ & $\begin{array}{l}0.50 \\
\mathrm{U} / \mathrm{ml}\end{array}$ & $\begin{array}{l}1.0 \\
\mathrm{U} / \mathrm{ml}\end{array}$ & $\begin{array}{l}1.5 \\
\mathrm{U} / \mathrm{ml}\end{array}$ & $\begin{array}{l}2.0 \\
\mathrm{U} / \mathrm{ml}\end{array}$ & \\
\hline Factor VIII chromogenic assay & 11.7 & 6.5 & 5.0 & 6.9 & 5.3 & - & 9.5 \\
\hline Factor VIII clotting assay & 18.6 & 21.0 & - & 17.5 & - & 17.9 & 28.4 \\
\hline
\end{tabular}

The $1 \mathrm{U} / \mathrm{ml}$ value of factor VIII in the chromogenic assay represents $20 \mu \mathrm{l}$ of human reference pool plasma in the final reaction mixture of $1 \mathrm{ml}$. The $100 \%$ value in the clotting assay is defined as the clotting time obtained when $0.1 \mathrm{ml}$ of a 1:20 dilution of the reference pool plasma is clotted in a 1-stage clotting assay for factor VIII with a final reaction volume of $0.4 \mathrm{ml}$. Reference pool plasma was obtained from 50 subjectively healthy donors ( 30 men, 20 women). Within-assay variation: coefficient of variation for measurements on the same day. Between-assay variation: coefficient of variation for measurements on different days.

Table III. Variation in normal values

\begin{tabular}{|c|c|c|c|c|c|c|c|}
\hline Assay & n & $\begin{array}{l}\text { Mean } \\
\text { factor VIII } \\
\text { activity, U/ml }\end{array}$ & $\begin{array}{l}\text { Inter- } \\
\text { individual } \\
\text { variation, } \%\end{array}$ & $\begin{array}{l}\text { Coefficient } \\
\text { of variation } \\
\text { assay, } \%\end{array}$ & $\begin{array}{l}\text { Range } \\
\mathrm{U} / \mathrm{ml}\end{array}$ & $\begin{array}{l}\text { Mean } \\
\triangle \mathrm{A} 405 / \mathrm{min}\end{array}$ & $\begin{array}{l}\text { Rate of } \mathrm{Xa} \\
\text { formation, } \\
\mathrm{n} M / \mathrm{min}\end{array}$ \\
\hline \multirow{3}{*}{$\begin{array}{l}\text { Factor VIII } \\
\text { chromogenic assay }\end{array}$} & $30 \mathrm{M}$ & 1.13 & 32.9 & & $0.53-2.29$ & 0.0203 & 2.85 \\
\hline & $20 \mathrm{~F}$ & 1.23 & 24.8 & & $0.73-1.97$ & 0.0221 & 3.10 \\
\hline & 50 & 1.17 & 29.7 & 6.9 & $0.53-2.29$ & 0.0210 & 2.95 \\
\hline \multirow{3}{*}{$\begin{array}{l}\text { Factor VIII } \\
\text { clotting assay }\end{array}$} & $30 \mathrm{M}$ & 1.07 & 26.2 & & $0.68-1.87$ & 4 & \\
\hline & $20 \mathrm{~F}$ & 1.23 & 24.8 & & $0.78-1.86$ & & \\
\hline & 50 & 1.14 & 26.3 & 17.5 & $0.68-1.87$ & & \\
\hline
\end{tabular}

$\mathrm{n}=$ Number of donors; $\Delta \mathrm{A}=$ absorbance change. The interindividual variation equals variation in normal values (see table II).

\section{Discussion}

In this paper, a spectrophotometric method for the determination of factor VIII in human plasma is presented. The method is based on the role of factor VIII as a nonenzymatic cofactor in intrinsic factor $\mathrm{X}$ activation. The assay consists of 3 steps: (1) incubation for $1 \mathrm{~min}$ of plasma (or a sample containing factor VIII) with thrombin to convert factor VIII to factor VIIIa; (2) incubation for 2 min of factor VIIIa with factor $\mathrm{IXa}$, factor $\mathrm{X}$ and phospholipid/ $\mathrm{Ca}^{2+}$ to allow factor $\mathrm{Xa}$ formation, and (3) determination of the amount of factor $\mathrm{Xa}$ in samples taken after 1 and $2 \mathrm{~min}$. Factor $\mathrm{Xa}$ is measured with the chromogenic substrate S2337 in the presence of EDTA to stop further fac- 
tor $\mathrm{X}$ activation. The rate of factor $\mathrm{Xa}$ formation is calculated and compared to the rate found with reference plasma. Factor VIII activity is expressed in units per milliliter, assuming that the factor VIII activity in reference pool plasma is $1 \mathrm{U} / \mathrm{ml}$.

The components used in the chromogenic assay are bovine clotting factors IXa, $\mathrm{X}$ and thrombin that were prepared by standard procedures and commercial available phospholipids. Saturating (excess) concentrations of factors IXa, $\mathrm{X}$ and phospholipids were chosen to minimize variations due to a slight activity change that might occur in these preparations.

Factor VIII was activated in a separate step at an optimal concentration of thrombin. When thrombin was omitted, no measurable amount of factor $\mathrm{Xa}$ is formed within the assay period of $2 \mathrm{~min}$. Factor Xa formation starts after 5-6 min, presumably as a result of factor VIII activation by traces of factor $\mathrm{Xa}$ and/or thrombin formed during the lag period. The finding that optimal factor VIII activation by thrombin could be obtained suggests that all factor VIII is converted to factor VIIIa. Consequently, the assay responds to the total concentration of factor VIII, irrespective of the activity state of factor VIII. By performing the factor VIII assay without thrombin, it might be possible to detect circulating factor VIIIa. The few plasma samples we have tested so far without thrombin showed no evidence for a presence of factor VIIIa.

The rate of factor $\mathrm{Xa}$ formation we find in plasma $(3 \mathrm{n} M \mathrm{Xa} / \mathrm{min})$ is proportional to the plasma factor VIII concentration and can be used to calculate the plasma factor VIII concentration. The thrombin activation experiments and the factor IXa saturation curve indicate that all plasma factors VIII participate in factor $\mathrm{X}$ activation. When it is assumed that factor VIII functions in a oneto-one stoichiometrical complex with factor IXa in the enzymatic unit, then the rate of factor $\mathrm{Xa}$ formation is proportional to the concentration of the limiting component in the complex, which is here the factor VIIIa concentration.

The maximal rate of factor $\mathrm{Xa}$ formation is $925 \mathrm{~mol} \mathrm{Xa} / \mathrm{min} / \mathrm{mol}$ enzyme. This indicates that $3.0 / 925 \mathrm{n} M$ factor VIII is present in the reaction mixture. In the assay, plasma is diluted 1:50, and hence, the plasma VIII concentration in plasma is $150 / 925=$ $0.16 \mathrm{n} M \pm 32 \%$. This value is in agreement with estimates by immunological methods [2].

The sensitivity of the chromogenic assay extends to plasma factor VIII levels of about $0.05 \mathrm{U} / \mathrm{ml}$, but at factor VIII concentrations of $0.10 \mathrm{U} / \mathrm{ml}$ and lower, the coefficient of variation increases. Low levels of factor VIII can be detected by including larger sample volumes in the reaction mixture. When factor VIII is determined in plasma, not more than $40 \mu \mathrm{l}$ plasma can be used if fibrin formation in the factor $\mathrm{X}$ activation mixture may prevent accurate sampling to the cuvette. Defibrination by Arvin is useful in that case. The absorbance change found after 2 min of factor Xa formation under standard conditions ( $20 \mu \mathrm{l}$ plasma per milliliter reaction mixture and $100 \mu \mathrm{l}$ sample per cuvette) is $0.0210 \Delta \mathrm{A} 405 / \mathrm{min}$. Up to 10 -fold higher absorbance changes when a larger fraction of the reaction mixture is transferred to the cuvette.

The coefficient of variation of the chromogenic assay varies between $5-7 \%$, whereas the precision of the clotting assay varies between 17 and $21 \%$. The same large assay variations of the clotting method have 
been observed in previous studies [4, 8, 9]. The diversity in reagents, methods and equipment that is used in clotting assays may account for the large interlaboratory variation observed in factor VIII determinations [10]. Introduction of the chromogenic assay with its superior reproducibility may allow standardization.

A spectrophotometric assay for factor VIII has been presented by Rosén et al. [11, 12] working at KabiVitrum Diagnostica. Details of their assay have not been disclosed, but as the assay presented here, their method is based on the factor $\mathrm{X}$ activation reaction. The precision and sensitivity of the Kabi assay is similar to ours.

Several groups have used immunoradiometric assays to quantify factor-VIIIcoagulant antigen in plasma [13-17]. Human allogeneic antibodies are used in these assays obtained from hemophilia A patients with circulating anti-VIII:C antibodies that developed after infusions of factor VIII preparations or from individuals that developed these antibodies spontaneously. The radioimmune assays are very sensitive and have been used to detect factor VIII levels of $0.01-0.03 \mathrm{U} / \mathrm{ml}$. The method depends on the availability of the antibodies which may prevent large-scale application; moreover, immunological methods are complicated by the fact that immunologically recognized factor VIII:C may not be functionally active in clotting reactions [13].

Factor VIII in normal individuals varied between 0.53 and $2.27 \mathrm{U} / \mathrm{ml}$, what results in a variation in normals of $29.7 \%$. Previously, we found a variation for factors VII, IX, X and prothrombin of 21.4, 11.0, 15.0, and $12.0 \%$, respectively [18], suggesting that the factors VII and VIII present in plasma in the lowest concentration and the shortest half- life tend to have the largest biological variation.

Factor VIII assays are carried out to detect hemophilia, to identify carriers of hemophilia, to check the potency of factor VIII preparations used to treat hemophilia and to control treatment.

For prenatal diagnosis of hemophilia [14], the assay can easily be scaled down such that the test can be carried out with small plasma volumes obtained by fetoscopy $[17,18]$.

\section{Acknowledgements}

We gratefully acknowledge the dedication and skill of Truus Janssen-Claessen, who prepared factors $\mathrm{X}$ and factor $\mathrm{IX}_{\mathrm{a}}$.

\section{References}

1 Hemker, H.C.: Why do hemophiliacs bleed. Scand. J. Haemat. (in press, 1984).

2 Hoyer, L.W.: The factor VIII complex: structure and function. Blood 58: 1-13 (1981).

3 Zimmerman, T.S.; Ruggeri, Z.M.: Von Willebrand's disease; in Spaet, Progress in hemostasis and thrombosis, vol 6, pp. 203-206 (Grune \& Stratton, New York 1982).

4 Hardisty, R.M.; Macpherson, J.C.; Ingram, G.I.C.: A one-stage factor VIII assay and its use on venous and capillary plasma. Thromb. Diath. haemorrh. 7: 215-229 (1962).

5 van Dieijen, G.; Tans, G.; Rosing, J.; Hemker, H.C.: The role of phospholipid and factor VIIIa in the activation of bovine factor X. J. biol. Chem. 256: 3433-3442 (1981).

6 Rosing, J.; Tans, G.; Govers-Riemslag, J.W.P.; Zwaal, R.F.A.; Hemker, H.C.: The role of phospholipids and factor $\mathrm{Va}$ in the prothrombinase complex. J. biol. Chem. 255: 274-283 (1980).

7 van Dieijen, G.; van Rijn, J.L.M.L.; GoversRiemslag, J.W.P.; Hemker, H.C.; Rosing, J.: Factor IXa-factor VIIIa interaction: enhanced factor IXa binding to phospholipids in the presence of 
factor VIlIa (Abstract). Thromb. Haemostasis 50: 256 (1983).

8 Palkuti, H.A.; Longberry, J.F.: A precision study of coagulation factor assay technics. Am. J. clin. Path. 59: 213 (1973).

9 Elödi, S.; Váradi, K.; Hollán, S.R.: Some sources of error in the one-stage assay of factor VIII. Haemostasis 7: 1-9 (1979).

10 Kocoshis, T.A.; Triplett, D.A.: CAP survey results for factor VIIl assays (1977-1978). Am. J. clin. Path. 72: 346-361 (1979).

11 Rosén, S.; Oswaldsson, U.; Blombäck, M.; Larrieu, M.; Nilsson, I.M.; Vinazzer, H.: A collaborative comparison of a chromogenic FVIII:C method with one- and two-stage clotting methods (Abstract). Thromb. Haemostasis 50: 112 (1983).

12 Rosen, S.; Carlebjörk, G.; Oswaldsson, U.: Determination of factor VIII:C activity in microtiter plates using the chomogenic COATEST factor VIII kit. Poster presentation at the 20th Congr. Int. Soc. Hematol. (1984).

13 Lazarchick, J.; Hoyer, L.W.: Immunoradiometric measurement of the factor VIII procoagulant antigen. J. clin. Invest. 62: 1048-1052 (1978).

14 Peake, I.R.; Bloom, A.L.; Giddings, J.C.; Ludlam, A.L.: An immunoradiometric assay for procoagulant factor VIII antigen: results in haemophilia, van Willebrand's disease and fetal plasma and serum. Br. J. Haematol. 42: 269-281 (1979).

15 Reisner, H.M.; Barrow, E.S.; Graham, J.B.: Radioimmunoassay for coagulant factor-VIII-related antigen (VIII:CAg). Thromb. Res. 14: 235-239 (1979).
16 Muller, H.P.; van Tilburg, H.N.; Bertina, R.M.; Terwiel, J.Ph; Veltkamp, J.J.: Immunoradiometric assay of procoagulant factor VIII antigen (VIIIcAG). Clinica chim. Acta 107: 11-19 (1980).

17 Hoyer, L.W; Trabola, N.C.: Immunoradiometric assays for factor VIII-antigens: coagulant protein C (autohemophobic factor) and factor-VIII-related protein (von Hillebrand factor). Meth. Enzym. 84: 51-60 (1982).

18 van Dieijen-Visser, M.P.; van Wersch, J.; Brombacher, P.J.; Rosing, J.; Hemker, H.C.; van Dieijen, G.: Use of chromogenic peptide substrates in the determination of clotting factors II, VII, IX and X in normal plasma and in plasma of patients treated with oral anticoagulants. Haemostasis 12: 241-255 (1982).

19 Firshein, S.I.; Hoyer, L.W.; Lazarchick, J.; Forget, B.G.; Hobbins, J.C.; Clyne, L.P.; Pitlick, F.A.; Muir, W.A.; Merkatz, I.R.; Mahoney, M.J.: Prenatal diagnosis of classic hemophilia. New Engl. J. Med. 300:937-941 (1979).

Received: May 3, 1985

Accepted in revised form: August 5, 1985

Prof. Dr. H.C. Hemker,

Department of Biochemistry,

University of Maastricht,

PO Box 616,

NL-6200 MD Maastricht (The Netherlands) 